\title{
An Analysis of the Scope of Judicial Overreach in the Context of Legislative Intent
}

\author{
Sreyan Chatterjee*
}

\begin{abstract}
Legislative intent is considered to be one of the aids to statutory interpretation. This article looks at the theoretical justifications behind usage of legislative intent as a tool of statutory interpretation. The monopoly of the legislature in law making is acknowledged by the judiciary when it examines the legislative intent in interpreting statutes. It is argued that this justification is obsolete and is being increasingly used as a cover for judicial lawmaking. Without getting into the pros and cons of judicial overreach, this article analyses the role of legislative intent-hunting in keeping alive the myth of legislative supremacy in India. This article calls for further research on the possibility of restriction of the use of terminology of 'legislative intent' in cases where it is clearly absent. On the contrary, where the gulf between statutory text and the intended effect is bridged using judicial standards and criteria, the said principle should be termed 'judicial intention'.
\end{abstract}

Keywords: Intention, Interpretation, Judiciary, Legislation, Policy.

\section{Introduction}

It is a commonly held view that the main purpose of the exercise of construction $^{1}$ of statute is to ascertain the intent of the legislature. ${ }^{2}$

* BA LLB (Hons.), West Bengal National University of Juridical Sciences, Kolkata; sreyan21@gmail.com. 
For decades, the judiciary has been making it clear that a substantial part of the process of interpretation is the search for legislative intent. ${ }^{3}$

There are three methods of statutory interpretation: Textual interpretation, analysis of legislative intent and analysis of extra legislative values. ${ }^{4}$ While a court can technically make use of all the three, different theories have stressed the influence of one over the other. Textualism demands from the courts, a plain analysis of the statutory text 5 ; intentionalism asks the courts to look into the intent of the drafters of the legislation; ${ }^{6}$ extra legislative or judicial activism theories would require the courts to go beyond the

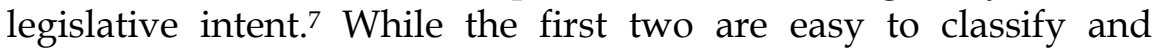

${ }^{1}$ (for the purposes of this paper, we will use the terms construction and interpretation interchangeably. The subtlety of the distinction between construction and interpretation is superfluous for the purposes of this paper. In short, while interpretation is adhering to the text and generally sticking to the ordinary meaning of the text, while construction is what is popularly called 'going beyond the text'). See Peter M. Tiersma, The Ambiguity of Interpretation: Distinguishing Interpretation from Construction, 73 WASH.U.L.Q 1095 (1995).

${ }^{2}$ Shiv Shakti Co-operating Housing Society v. Swaraj Developers, (2003) 1 S.C.C. 659; Union of India v. Devki Nandan Agarwal, A.I.R. 1992 S.C. 96.

${ }^{3}$ Prithi Pal Singh v. Union of India, A.I.R. 1982 S.C. 1413; United States v. Raymor 302 U.S. 540, 542.

${ }^{4}$ Edward O' Correia, A Legislative Conception of Legislative Supremacy, 42 CASE W. RES. L. REV. 1129, 1139 (1992).

${ }^{5}$ (the theory of textualism is also referred to as the 'plain meaning rule'). See generally Frank. H. Easterbrook, Statutes' Domain, 50 U.CHI.L. REV. 533 (1983); William N. Eskridge Jr., The New Textualism 37 UCLA L. REV. 621 (1990).

${ }^{6}$ (one of the foremost proponents of intentionalism is Justice Posner). See Richard A. POSNer, THE FEDERAl COURTS: CRISIS AND REFORM, 285293(1985); See generally Earl M. Maltz, Statutory Interpretation and Legislative Power: The Case For a Modified Intentionalist Approach 63 TUL. L. REV. 1 (1988).

7 (there have been other methods of classification, the most prominent being that of Eskridge and Frickey wherein they talk about textualism, intentionalism and purposive interpretation. They also come up with a fourth sub-category in their paper namely 'practical reasoning'). See 
understand, the last is difficult to be defined exhaustively. ${ }^{8}$ For the purposes of this paper, we cannot limit any theory into the first two categories. We will classify it under the third head, judicial activism. ${ }^{9}$

It is a well accepted canon of interpretation that where the language of the statute is clear, unambiguous and free from reasonable doubt, the judiciary should refrain from looking into the legislative intent. In practice, it is seen that the sensitive clauses in statutes are not drafted plainly because there is a need to allow flexibility of interpretation. When litigation over such clauses reaches the higher judiciary, the concept of legislative intent gives a free hand to the judiciary. There is a reasonable apprehension that under the guise of finding legislative intent, the courts may interfere with the policy matters. To analyse the extent to which the hands of the judiciary are tied by legislative intent, we have to go back to our understanding of legislative intent and the role it plays in interpretation. In the introductory section, the basic questions about the presence of legislative intent and the difficulty in locating it are addressed. In the next two sections, the jurisprudential groundings behind the use of legislative intent to bridge ambiguity are analysed in the light of the doctrine of legislative supremacy in law making. The concluding section addresses the different questions that have been raised in this article.

\section{The Fiction of Legislative Intent}

Jurisprudential debates around the legislative intent have been on the rise. The foundation of these arguments had been laid in the Radin-Landis debate which sparked off in 1930, when Max Radin claimed that actual statutory intent is hard to come by and the probabilities of finding it in the legislative records are extremely

William N. Eskridge and Philip P. Frickey, Statutory Interpretation as Practical Reasoning, 42 STAN. L. REV. 321, 324 (1990).

${ }^{8}$ Edward O' Correia, A Legislative Conception of Legislative Supremacy, 42 CASE W. RES. L. REV. 1129, 1141 (1992).

${ }^{9}$ (this is a matter of perspective. Some would argue that the policy making on the part of the judges is not judicial interpretation but rather interpretation of the actual purpose of the legislation). 
low. ${ }^{10}$ Radin argued that legislative intent was a legal fiction and there was no reason to continue the judicial enquiry into the said intent. Landis responded to this by claiming that there was a fundamental difference in the two types of intent: firstly, intent as 'intended meaning' and intent as 'intended purpose'. His claim is that the former is more easily established and can be found in the legislative document. ${ }^{11}$ The Radin-Landis debate is still one of the most referred, yet most misunderstood debates in statutory interpretation. As McCallum points out ${ }^{12}$, the scholars who have taken the Radin line have typically failed to understand that legislative intent and purpose are the same. ${ }^{13}$

This problem with classification of legislative intent under various heads to prevent arguments was resolved to a certain extent by Richard Nunez. He proposed three heads of legislative intent: First, legislative intent with regard to the 'solution of general social problems'; ${ }^{\prime 4}$ second with regard to the general purpose behind the enactment of a particular statute and third, legislative intent with regard to the meaning of a specific word in the said statute. From this classification, it is clear that Radin's assertion that legislative intention is absent is only partially true. When one elevates judicial viewpoint to a certain level of generality, it is possible to distill a 'clear and discernable' 15 legislative intent. This level of generality is not applicable when we speak of legislative intent with regard to specific meaning of a word in a statute. This is a significant setback

\footnotetext{
${ }^{10}$ Max Radin, Statutory Interpretation, 43 HARV. L. REV. 863 (1930).

11 James Landis, A Note on 'Statutory Interpretation', 43 HARV. L. REV. 886 (1930).

12 Gerald C. McCallum, Legislative Intent, 75 YALE L.J. 754 (1966).

13 John Willis, Statutory Interpretation in a Nutshell, 16 CAN. BAR. REV. 1 (1938); Felix Frankfurter, Some Reflections on the Reading of Statutes, 47 COLUM. L. REV. 527 (1947); Max Radin, A Short Way with Statutes, 56 HARV. L. REV. 388 (1942).

14 Richard I. Nunez, The Nature of Legislative Intent and the Use of Legislative Documents as Extrinsic Aids to Statutory Interpretation, 9 CAL. W.L. REV. 128, 129 (1973).

$15 \mathrm{Id}$. at 130 .
} 
to this analysis because most of the debate around legislative intent concerns this category. ${ }^{16}$

Taking a different stance from Nunez, Dworkin insisted upon the concept of institutionalized intent. ${ }^{17} \mathrm{He}$ opined that legislative intent is of two types: institutionalized and collective. ${ }^{18}$ Accordingly, Radin's criticism was confined only to collective intention which is a psychological concept consisting of combined belief of legislature. ${ }^{19}$ On the other hand, institutionalized intent is the direction of policy that has been determined by the legislature by which every legislator is bound even if he had opposed it. Dworkin builds his coherence theory of statutory interpretation on this logic. It is indeed true that many of the objections around the viability of legislative intent vanish but it lays down new questions on how one excludes evidence which does not adhere to the institutionalized intent. Such intent should be free of doubt, in a manner as to exclude such evidence, rendering the institutionalized intent in tune with the proposed policy.

In short, it is clear that the extremes taken by the Radin-Landis debate is untenable. Radin's assertion that a small group of people can never have legislative intent is reflective of the legislative purposes of specific interpretation. At higher levels of generality it is easier to find a common legislative intent but that intent is hardly ever useful to the judiciary. ${ }^{20} \mathrm{As}$ such we must keep this distinction in mind in our search for legislative intent. Simply put, if the intent is easily found, then the intent must be purposive, general and possibly more inclusive. On the other hand, if the intent is not that apparent, then the search for specific legislative intent might not be fruitful and inclusive. As the author argues in the later part of this

16 Id. at 129.

17 See RONALD DWORKIN, LAW's EMPIRE 313-54 (1986); RONALD DWORKIN, A MATTER OF PRINCIPLE 316-31 (1985).

18 RONALD DWORKIN, A MATTER OF PRINCIPLE 320 (1985).

19 Peter C. Schanck, An Essay on the Role of Legislative Histories in Statutory Interpretation, 80 LAW LIB. J. 391, 405 (1988).

${ }^{20}$ (note that the common legislative intent is not a sum of legislative intent of legislators but rather the commonality of reasons which led them to enact the said statute). 
paper, it is the latter kind of search that provides the opportunity for judicial overreach. ${ }^{21}$

\section{Search for Legislative Intent}

Having established the nature of legislative intent in the preceding section, it is clear that while legislative intent is largely a legal fiction, it is relevant too. It is, but a bridge which connects different discrete parts in the process of interpretation. ${ }^{22}$ It is a search where the means are more important than the end. Using legislative intent as a lens with which to view a statute, the judiciary would be able to distill the true meaning of a statute. However, before one analyses the relationship of the judiciary with the search for legislative intent, it is important that one contextualizes the places where legislative intent may be reasonably found.

With regard to the question of where legislative intent may be found, a broad division can be effected in relation to its origin. It may be found within the statute, in legislative documents and in non legislative documents. ${ }^{23}$ For the present purpose, the focus is on the first two sources, internal and external aids to legitimate interpretation.

It is a well evolved canon of construction that the best manner of understanding the meaning of the statute is to look into the statute itself. Internal aid to statutory interpretation in case of ascertaining legislative intent is a particularly strong argument. Statute making is a question of compromise and careful drafting where sentences are constructed to achieve the consensus of the critical majority of the legislature. Making use of internal aids to interpretation is the first advisable step in understanding the common consensual intent

21 (it is opined by many scholars that the search for legislative intent should be restricted to purposive intent and not be extended to specific intent). See Elizabeth Garett,William N. Eskridge and Philip P. Frickey, Legislation Scholarship and Pedagogy in the Post Legal Process Era, 48 U. PITT. L. REV. 691, 699(1987).

22 Richard I.Nunez, The Nature of Legislative Intent and the Use of Legislative Documents as Extrinsic Aids to Statutory Interpretation, 9 CAL. W.L. REV. 128 (1973).

${ }^{23} \mathrm{Id}$. at 131. 
of the legislature. The reasonable presumption we can make here is the fact that a particular word finding itself a place in the statute is enough to assume it has the support of the critical majority of the legislature. When we look at the documents that are prepared during the legislative process in the light of the above presumption, it is clear that the search for intent in external documents would present conflicting viewpoints. During the same deliberation there is a possibility that another legislator delivers a speech taking a fundamentally different stand and only one of their views is accommodated in the final statute. Putting these materials on the same standing would open up avenues of incorporating a meaning to the law which was not accepted by the majority of the legislature. Thus when courts turn from internal to external evidence of legislative intent, it is important that this distinction is internalized and importance to such evidence is accorded.

\section{Taking Cognizance of Legislative Intent}

Legislative intent is taken note of in two circumstances. ${ }^{24}$ Firstly, when the statute cannot be comprehended because of the style of drafting or because of the words being used. Secondly, when the language of the statute is clear but the circumstances which have arisen were not envisaged by the legislature. ${ }^{25}$

\section{Legislative Supremacy vs. Legislative Intent}

Legislative supremacy holds true in determining public policy. Prima facie this concept sounds simple, but in reality the grey areas around this distinction has lead to confusion. ${ }^{26}$ The first caveat that one should understand in the study of the legislative supremacy is it's distinction with legislative exclusivity. Generally, these two

\footnotetext{
24 Supra note 22.

${ }^{25} \mathrm{Id}$.

26 (the series of landmark Supreme Court decisions from 1970s onward determining public policy and the repeated attempts of the legislature is well known and this tussle continues back and forth. While it provides an interesting context to our theoretical discussion, a detailed view would be a surplus to the requirements of this present paper).
} 
concepts are quite distinct from each other. ${ }^{27}$ While supremacy of legislature holds true most of the times, legislative exclusivity is rare. Typically courts lay down their version of public policy, which may be subject to later amendments and modifications which may be carried out by the legislature. When we admit the possibility that law making is not an absolutely restricted domain of the judiciary, the question of how far the judiciary is allowed access to examine the legislative intent would arise. When we examine the scope of this legislative restraint, we depart from the scholarly consensus in statutory interpretation and venture into the differing notions of legislative supremacy.

A strong or formalist conception of supremacy would disallow courts from using any other values other than the ones endorsed by the legislature.28 Stated simply, this notion means that the courts should stay within the ambit of legislative directives. ${ }^{29}$ The role of judges is to interpret the statue and apply the interpretation in the light of the differing facts. Holding such an expansive view might not be of any practical use as it precludes the court from using its own values even when the legislature delegates such policy making power 30 This strong notion of legislative supremacy restricts the judiciary, not only from the domain of public policy but also from important adjudicatory tools such as stare decisis unless the legislature has explicitly endorsed such a use. The flaw in this notion of legislative supremacy is clearly in the presumption that it is possible for the legislature to explicitly provide for all the probabilities. When the legislature has enacted clear, unambiguous laws, this interpretation holds good. More often than not, this does not happen and the courts may have to interpret in cases where the legislature has been vague.

27 Peter Westen \& Jeffery S. Lehman, Is there a Life for Erie after the Death of Diversity?,78 MiCH. L. REV. 322, 326, 331 (1980).

28 Daniel A. Farber, Statutory Interpretation and Legislative Supremacy, 78 GEO L.J. 281, 284 (1990).

29 See Frank H. Easterbrook, Foreword, The Court and the Economic System, 98 HARV. L. REV. 4, 60 (1984).

30 Edward O' Correia, A Legislative Conception of Legislative Supremacy, 42 CASE W. RES. L. REV. 1129, 1146 (1992). 
The judiciary acting as sole the interpreter of the laws is useful but there is an element of oversimplification of the strong notion of legislative supremacy. While the Judiciary interprets a statute, some discretion is exercised by it in decision making. This ambit of discretion is lost if we subscribe to the notion of supremacy. Secondly, it is arguable that the Supreme Court and the High Courts are not agents of the legislature, but of the Constitution. Clearly, the strong conception of supremacy applies only if the law is clear, unambiguous and is in line with the public policy laid down by the legislature in the past, and since these conditions hardly ever hold true, judicial law making is inherent in interpretation. ${ }^{31}$

Legislative supremacy is also perceived as a restriction upon the actions of the judiciary. It says that the judiciary should not go against the explicit directives laid down by the legislature. Instead of saying the judiciary should always obey as in the strong supremacy model, it is saying that the judiciary cannot explicitly disobey. The advantage of adhering to the weak supremacy model is that it does not require a consensus on what grounds public policy is invoked by the judiciary. There is an inherent presumption that a statute does not have one correct interpretation. From a set of correct interpretations, the legislature will mostly debar a certain number of interpretations, leaving the field clear for the judiciary to choose from the reduced subset of interpretations. Basically, the weak conception of legislative supremacy is a negative definition which in a way resolves ambiguity present in the strong conception.

When one tries to pin down what constitutes disobedience, ${ }^{32}$ to the above mentioned rule, it would take him back to the first position. However, it is clear that the judiciary does not have to go in search of the intent of the legislature at the point of framing the

${ }^{31}$ See Richard A. Posner, Statutory Interpretation: In the Classroom and the Courtroom, 50 U. CHI. L. REV. 800, 816 (1983); Blatt, The History of Statutory Interpretation: A Study in Form and Substance, 6 CARDOZO L. REV. 799, 800805, 813-815, 833.

32 See H.L.A. HART, THE CONCEPT OF LAW 18-26 (1961). 
legislation. ${ }^{33}$ Instead the search should be confined to the intent that can found in the text.

Hence, it is clear from the above discussion that the weak model of legislative supremacy, allows maximum authority to both the legislature and the judiciary. The elected representatives, if they believe that certain interpretations should not be resorted to, always have the option of explicitly denying the judiciary the option of that particular interpretation. At the same time, the necessary room for the judiciary is not curtailed. This room for manoeuver is essential because a scenario that the legislature has occasion to legislate for all possibilities which may arise out of a particular issue is slim.

\section{Conclusion}

The search for legislative intent has yielded several results; most importantly, one cannot narrowly define intent if the structure of judicial review is to be preserved. Legislative intent when allowed to be expanded takes the shape of a legal fiction, albeit a necessary fiction, to help the judiciary to narrow the gap between the purpose of the legislation and the text of the legislation. In many cases this gap is not present and the role of the judiciary is restricted (or at least should be) to apply the law without resorting to legislative intent. Secondly, when there is a gap because of reasons such as information asymmetry, the legislature takes note of the gap, the fact that the legislature does not have the ability to bridge the gap, confers powers to the judiciary to bridge the gap. In this case, the weak supremacy principle comes to our aid, as the judiciary can bridge the said gap by any means as long as it does not vitiate the guidelines of the legislature. The problem comes with this scheme of things, when there is a gap and such gap has not been appreciated by the legislative intent. Bridging this gap by the judiciary is not subject to any checks and this is justified by the invocation of the concept of legislative intent. It is clear that this legislative intent (frequently called purposive intent or

33 Charles Fried, Sonnet LXV and the 'Black Ink' of the Framers' Intention, HARV. L. REV. 751, 758-759 (1987); See Tribe, Judicial Interpretations of Statutes: Three Axioms, 11 HARV. J. L. PUB. POL'Y. 51 (1988). 
institutionalized intent) in the third instance is substantially different from the legislative intent used in the first two instances. The argument does not answer the question as to whether there is sufficient justification for this extent of judicial activism rather it questions the need for couching judicial activism in terms of legislative intent. In the limited scope of this note, it is suggested that such invocation of intent should be divorced from the other uses of legislative intent. Perhaps the term 'judicial intent' is more appropriate when the judiciary uses its own standards to bridge gaps between the statutes and their final effect. 